\title{
PENERAPAN SWOT DALAM PENENTUAN STRATEGI PEMASARAN PADA UMKM SUNMORY MILK SIDOARJO
}

\author{
Iswahyudi Pratama ${ }^{1}$, Lukluk Ilmaknun ${ }^{2}$, Shinta Wardatuz Zuhriyah ${ }^{3}$, Leonard Adrie Manafe ${ }^{4}$ \\ Sekolah Tinggi Ilmu Ekonomi Mahardhika Surabaya \\ *Email : leonard.adrie@stiemahardhika.ac.id
}

\begin{abstract}
The research topic is related to the food and beverage business so it needs to be a serious concern for the company so that the products consumed are right on target. Moreover, business competition is very tight in the culinary industry. For this reason, researchers conducted research with the aim of knowing and analyzing the SWOT analysis which was used as the basis for determining the right marketing strategy for the Sunmory Milk company. The method used is a descriptive approach by distributing questionnaires to 31 Sunmory Milk consumers as research informants. The location of the business is in Granting Village, Gedangan, Sidoarjo, East Java. From the research results, the key is that the strength of Sunmory Milk products is an affordable price with premium taste quality and innovation that makes Sunmory Milk beverage products different from other products. There are weaknesses in the number of inadequate workforce and poor time management arrangements. The opportunity for Sunmory Milk is that there are not many similar competitors in the area of business location so as to expand the business and increase the company's income. The threat of business is similar to the company's strengths related to product quality, product packaging and price competition.
\end{abstract}

Keywords: SWOT, Marketing Strategy, SME.

ABSTRAK : Topik penelitian terkait dengan usaha makanan dan minuman sehingga perlu menjadi perhatian serius perusahaan agar produk yang dikonsumsi pelanggan tepat sasaran. Apalagi terdapat persaingan bisnis yang sangat ketat dalam industri kuliner. Untuk itu, peneliti melakukan penelitian dengan tujuan untuk mengetahui dan menganalisa metode SWOT Analysis yang dijadikan dasar untuk menentukan strategi pemasaran yang tepat pada perusahaan Sunmory Milk. Metode yang digunakan melalui pendekatan kualitatif deskripsi dengan melakukan penyebaran kuesioner kepada 31 konsumen Sunmory Milk sebagai informan penelitian. Lokasi usaha terletak di Desa Granting, Gedangan, Sidoarjo, Jawa Timur. Dari pembahasan hasil penelitian disimpulkan bahwa kekuatan dari produk Sunmory Milk adalah harga yang terjangkau dengan kualitas rasa yang premium dan inovasi yang membuat produk minuman Sunmory Milk beda dengan produk yang lainnya. Terdapat kelemahan dalam jumlah tenaga kerja yang kurang memadai dan pengaturan manajemen waktu yang kurang baik. Peluang Sunmory Milk yaitu belum banyaknya pesaing sejenis diarea lokasi usaha sehingga berpeluang untuk melakukan pelebaran usaha dan peningkatan pendapatan perusahaan. Ancaman adanya kesempatan usaha sejenis meniru kekuatan perusahaan terkait mutu produk, kemasan produk dan persaingan harga. 


\section{PENDAHULUAN}

Dewasa ini perusahaan dituntut tampil beda dan mampu bersaing diantara perusahaan sejenis dengan menunjukan berbagai keunggulan produk maupun jasa masing-masing. Keunggulan produk atau jasa ini akan menjadi dasar penentuan tercapai atau tidaknya suatu target perusahaan. Penentuan rencana usaha harus benar-benar dibuat dan ditetapkan dengan akurat agar dapat diketahui arah dan tujuan perusahaan, cara pencapaian serta langkah perusahaan untuk bertindak dengan memaksimalkan segenap kekuatan dalam merebut ketersediaan kesempatan bisnis. Oleh sebab itu, demi tercapainya suatu kegiatan usaha yang efektif dan efesien maka dipandang perlu membuat suatu perencanaan yang baik dan keakuratan analisa bisnis. Pada umumnya, perusahaan menggunakan analisa SWOT (Strengths, Weaknesses, Opportunities, Threats) untuk mendukung tercapainya perencanaan bisnis yang telah ditetapkan.

SWOT Analysis adalah suatu analisa faktor yang sistematis dan logis untuk memformulasikan strategi perusahaan dengan upaya untuk memaksimalkan kekuatan dan peluang dan secara bersamaan juga bisa meminimalkan kelemahan dan ancaman (Rangkuti,
2016:19). SWOT Analysis merupakan suatu cara yang dipakai untuk melakukan evaluasi dan pemilahan berbagai isu terhadap kekuatan, kelemahan, peluang dan ancaman perusahaan untuk menghadapi spekulasi usaha (Puguh, 2016)

Kegiatan pemasaran atas produk atau jasa dalam memenuhi keinginan dan kebutuhan konsumen dapat dikatakan berjalan dengan lancar apabila analisis SWOT dilakukan dengan baik. Konsep strategi dipandang perlu diterapkan dalam aktivitas pemasaran agar produk atau jasa yang diciptakan oleh perusahaan bisa dengan cepat dikonsumsi langsung oleh konsumen.

\section{SWOT Analysis}

Internal analysis : a) Analisis kekuatan/strengths, faktor kelebihan yang memberikan dukungan penuh kepada perusahaan berupa canggihnya alat teknologi, keahlian sumber daya, pemasaran dan basis pelanggan yang kuat, investasi modal keuangan yang besar, image produk yang unggul dipasaran serta relasi bisnis pembeli dan pemasok yang terjalin baik; b) Analisis kelemahan/weaknesses, merupakan faktor kebalikan dari kekuatan yang dapat menghambat dalam pencapaian tujuan perusahaan, seperti : fasilitas yang minim, 
Revised: July, 142021

Available online : July, 152021

sumber keuangan yang kurang memadai, kemampuan dan keahlian yang rendah dalam mengelola bisnis dan image perusahaan yang jelek.

\section{External analysis : a) Analisis} peluang/opportunities, faktor lingkungan yang membawa hal positif dan bermanfaat bagi perusahaan. Hal ini terkait kebijakan pemerintah, teknologi yang mengalami perubahan, pertumbuhan ekonomi dan relasi bisnis yang bertumbuh positif antara konsumen dan pemasok; b) Analisis ancaman/threats, faktor lingkungan yang membawa hal negatif dan merugikan bagi perusahaan. Hal ini sering terlewatkan dan kurang menjadi perhatian serius perusahaan sehingga perusahaan selalu mengambil langkah kontroversi atau berlawanan arah. Semangat dalam bersaing menjadi kendur dengan masuknya new competitor, perkembangan pasar yang terhambat, adanya kekuatan dalam melakukan tawar menawar antara pemasok dan konsumen, perubahan teknologi serta diberlakukan kebijakan baru pemerintah.

\section{Matrix SWOT}

Matrix SWOT merupakan suatu alat analisis yang digunakan untuk membantu dalam penyusunan faktor internal dan faktor eksternal terkait strategis perusahaan yang diambil (Rangkuti, 2017:83-84).
Dalam matriks ini akan disusun untuk mengetahui dengan jelas bagaimana mempertemukan kekuatan dan kelemahan yang dimiliki perusahaan dengan peluang dan ancaman yang dihadapi perusahaan. Pembuatan matriks ini bertujuan untuk mengetahui kemungkinan alternatif strategis terkait kekuatan, kelemahan, peluang dan ancaman.

\section{Strategi Pemasaran}

Berbicara strategi pemasaran akan muncul hal-hal terkait serangkaian target, maksud dan tujuan serta peraturan dan kebijakan yang akan memberikan pedoman atau petunjuk bagi perusahaan terhadap arahan yang jelas dan tepat dalam melakukan kegiatan pemasaran sepanjang waktu pada setiap tingkatan, acuan dan alokasinya. Lebih lagi terkait tanggapan yang cepat dari perusahaan terhadap lingkungan yang dapat mengubah kondisi dalam persaingan.

Strategi pemasaran adalah suatu upaya yang dilakukan oleh perusahaan terkait pengaruh dari aktivitas pemasaran terhadap permintaan produk pada sasaran lini pasar tertentu (Chandra, 2017). Permintaan produk dalam hal ini terkait dengan perubahan harga produk dipasaran, kampanye iklan yang telah dimodifikasi, rancangan akan promosi khusus akan 
Revised: July, 142021

Available online : July, 152021

produk dan pilihan jalur penyaluran yang tepat.

Strategi pemasaran adalah seperangkat rencana yang komprehensif, terpadu dan saling memiliki keterkaitan pada kegiatan pemasaran berdasarkan pedoman yang akan dijalankan demi pemenuhan tujuan perusahaan (Assauri, 2017).

Strategi pemasaran merupakan suatu cerminan keputusan bijaksana yang ditetapkan oleh perusahaan dalam menentukan dan menerangkan akan sasaran, maksud atau tujuan perusahaan sehingga tercapainya jangkauan bisnis perusahaan (Nizar, 2016). Beberapa indikator dalam strategi pemasaran antara lain : a) Product, unsur terpenting dalam suatu kegiatan pemasaran adalah produk. Oleh sebab itu, penentuan strategi produk harus menjadi perhatian serius perusahaan karena akan berpengaruh terhadap strategi lainnya. Pembelian akan suatu produk benar-benar sesuai dengan kebutuhan dan keinginan konsumen itu sendiri; b) Price, beban yang dikeluarkan oleh konsumen untuk mendapatkan produk atau jasa. Harga juga menjadi penentu faktor penting bagi konsumen sebelum pengambilan keputusan untuk melakukan atau tidaknya transaksi pembelian; c) Promotion, suatu kegiatan pemasaran terkait perpindahan informasi dari penjual kepada pembeli atau pihak lain yang akan berpengaruh terhadap sikap dan perilaku konsumen. Jenis dan bentuk produk akan dijadikan pertimbangan perusahaan dalam menentukan media iklan yang akan dipakai; d) Place, indikator tempat berhubungan dengan selengkap institusi yang berperan dalam penyaluran produk dan kepemilikan status dari penjual ke pembeli. Kemudahan dalam mencari dan memperoleh suatu produk berhubungan erat dengan baik atau tidaknya sistem penyaluran; e) People, keterlibatan orang baik langsung maupun tidak langsung di dalam proses pelayanan dan penjualan; f) Process, tahapan kegiatan selama terjadinya transaksi antara penjual dan pembeli yang dimulai dari tahapan penawaran, sistem pembayaran, pengiriman produk dan sampainya produk ke pihak konsumen. Proses yang baik akan berpengaruh terhadap citra perusahaan; g) Physical evidence, hal lain dalam kegiatan pemasaran yang harus mendapatkan perhatian perusahaan terkait dengan penyediaan fasilitas pendukung. Karena penyampaian suatu jasa kepada konsumen tidak jarang membutuhkan fasilitas pendukung. 
Di kota Sidoarjo, minuman dengan olahan susu sudah mulai marak. Hal ini terkait dengan minuman susu di Indonesia sedang populer dengan berbagai macam olahannya dan sudah banyak brand besar yang menjual produk minuman berolahan susu. Salah satu Usaha Mikro Kecil Menengah (UMKM) yang berada di kota Sidoarjo memiliki usaha yang bergerak dalam bidang penjualan minuman dengan olahan susu dengan merek "Sunmory Milk".

Dengan melihat latar belakang dan kajian teoritis pendukung diatas, peneliti ingin melakukan suatu penelitian terkait obyek Sunmory Milk dengan tujuan riset adalah untuk mengetahui manfaat dan cara penerapan analisis SWOT sebagai penentu strategi pemasaran pada UMKM Sunmory Milk di Sidoarjo.

\section{METODE PENELITIAN}

\section{Desain Penelitian}

Pendekatan kualitatif deskriptif yang digunakan dalam penelitian ini. Metode ini memperhatikan kondisi obyek yang alamiah berdasarkan filsafat postpositivisme (Sugiyono, 2016:15). Penelitian dilakukan pada UMKM Sunmory Milk yang berlokasi di Desa Granting, Gedangan, Sidoarjo. Waktu penelitian dimulai awal Maret dan berakhir pada Mei 2021.

\section{Popolasi dan Sampel Penelitian}

Populasi dalam penelitian ini yaitu konsumen atau pembeli produk olahan susu Sunmory Milk. Sampel sebanyak 31 orang yang bertempat tinggal dekat dengan lokasi usaha. Teknik pengambilan sampel penelitian berdasarkan teknik purposive dan snowball.

\section{Definisi Operasional}

Variabel penelitian yaitu analisis SWOT, mengidentifikasi dan menguraikan faktor-faktor menjadi kekuatan dan kelemahan perusahaan serta peluang dan ancaman yang dihadapi perusahaan akan berpengaruh terhadap variabel penentuan strategi pemasaran (produk, harga, promosi, tempat, orang, proses dan bukti fisik) demi tercapainya tujuan perusahaan.

\section{Teknik Pengumpulan Data}

Teknik pengumpulan data dengan triangulasi (gabungan). Data diperoleh dari pembagian kuesioner dengan memberikan beberapa pertanyaan terkait indikator strategi pemasaran. Selain itu data yang digunakan juga berdasarkan uraian data terkait faktor internal dan eksternal perusahaan. Data internal, uraian terkait kekuatan dan kelemahan perusahaan dan data eksternal terkait peluang dan ancaman yang dihadapi perusahaan. 
Revised: July, 142021

Available online : July, 152021

\section{Teknik Analisis Data}

Teknik analisis data yang digunakan dalam penelitian ini adalah analisis data bersifat induktif/kualitatif dan hasil penelitian kualitatif lebih menekankan makna dari pada generalisasi.

\section{HASIL DAN PEMBAHASAN}

\section{Hasil penelitian}

Hasil penelitian yang diperoleh dari penyebaran kuesioner kepada 31 informan Sunmory Milk dapat dilihat pada uraian dibawah ini:

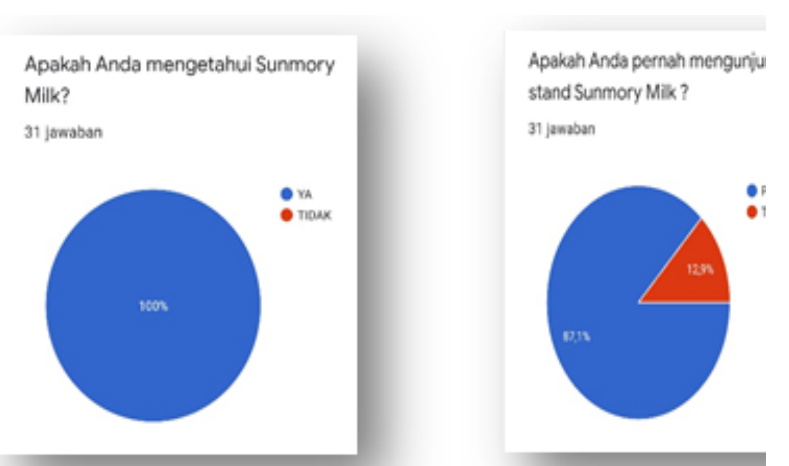

Gambar 1. Pengenalan Produk dan

\section{Kunjungan}

Berdasarkan Gambar 1, terlihat tanggapan dari 31 sample menyatakan bahwa $100 \%$ informan mengetahui produk Sunmory Milk. 87,1\% dari total informan lebih mengenal produk Sunmory Milk karena seringnya mengunjungi stand produk sedangkan sisanya $12,9 \%$ tidak pernah melakukan kunjungan langsung.
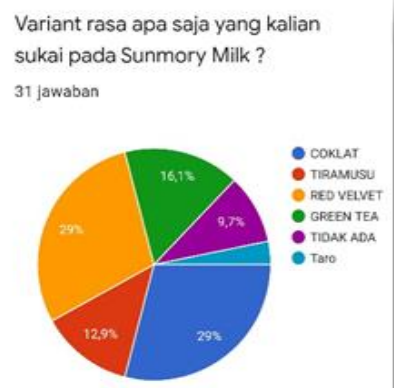

Gambar 2. Varian Rasa \& Harga Produk Sunmory Milk

Berdasarkan Gambar 2 tersebut dapat diuraikan masing-masing $29 \%$ dari total informan memilih varian rasa coklat dan red velvet. $16,1 \%$ dari total varian memilih rasa green tea. $12,9 \%$ dari total informan memilih rasa tiramisu. $9,7 \%$ dari total informan memilih rasa taro dan 3,3\% dari total informan tidak ada atau belum pernah mencoba.

Terkait harga produk seluruh informan berpendapat bahwa harga produk Sunmory Milk cukup terjangkau.

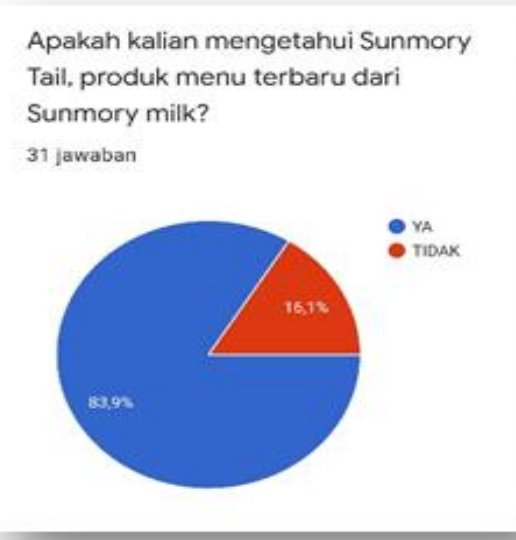

Gambar 3. Varian Produk Baru Sunmory Tail

Berdasarkan informasi pada Gambar 3, Sunmory Milk memproduksi produk 
Revised: July, 142021

Available online : July, 152021

varian baru dengan nama Sunmory Tail.

$89,9 \%$ dari total informan mengetahui

produksi produk baru dan sisanya $16,1 \%$

belum mengetahui adanya produk baru.

Rasa produk baru yang diproduksi terdiri atas rasa blue ocean, red sweety, blue blood dan orange squash.

Apakah Anda puas dengan

pelayanan dari Sunmory Milk?

31 jawaban

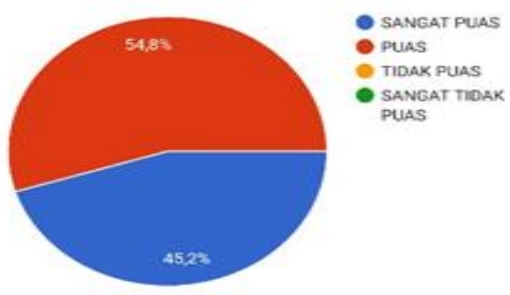

Gambar 4. Kepuasan Pelayanan Konsumen Sunmory Milk

Merujuk pada Gambar 4 menunjukan $54,8 \%$ informan merasa puas dan $45,2 \%$ informan merasa sangat puas terhadap pelayanan yang diberikan Sunmory Milk. Berarti dapat disimpulkan dari hasil tanggapan kuesioner bahwa seluruh informan tidak meragukan atau beropini positif terhadap layanan konsumen yang diberikan Sunmory Milk.

\section{Analisis SWOT}

Tabel 1. Matrix SWOT Sunmory Milk

\begin{tabular}{|c|c|c|}
\hline & Strengths $(S)$ & $\begin{array}{c}\text { Weaknesses } \\
(W)\end{array}$ \\
\hline & $\begin{array}{l}\text { a. Murahnya } \\
\text { harga } \\
\text { produk. } \\
\text { b. Minuman } \\
\text { yang }\end{array}$ & $\begin{array}{l}\text { a. Kurangn } \\
\text { ya tenaga } \\
\text { manusia. } \\
\text { b. Kurang } \\
\text { tertibnya }\end{array}$ \\
\hline
\end{tabular}

\begin{tabular}{|c|c|c|}
\hline EFAS & $\begin{array}{l}\text { menyehatka } \\
\text { n. } \\
\text { c. Kritin \& } \\
\text { saran } \\
\text { konsumen } \\
\text { yang selalu } \\
\text { diterima } \\
\text { dengan } \\
\text { baik. }\end{array}$ & $\begin{array}{l}\text { dalam } \\
\text { mengatur } \\
\text { waktu. } \\
\text { c. Bahan } \\
\text { baku } \\
\text { yang } \\
\text { digunaka } \\
\text { n } \\
\text { tergolong } \\
\text { murah } \\
\text { d. Tidak } \\
\text { tahan } \\
\text { lama atas } \\
\text { produk } \\
\text { yang } \\
\text { dihasilka } \\
\text { n. }\end{array}$ \\
\hline $\begin{array}{l}\text { Opportunit } \\
\text { ies }(O)\end{array}$ & $\begin{array}{c}\text { Strategies ( } S- \\
O)\end{array}$ & $\begin{array}{c}\text { Strategies } \\
(W-O)\end{array}$ \\
\hline 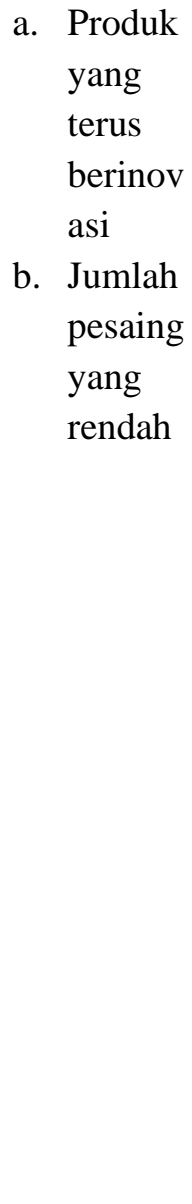 & $\begin{array}{l}\text { a. Tergolong } \\
\text { murah } \\
\text { untuk harga } \\
\text { produk, } \\
\text { produk } \\
\text { yang dijual } \\
\text { menyehatka } \\
\text { n, pesaing } \\
\text { produk } \\
\text { masih } \\
\text { kurang } \\
\text { sehingga } \\
\text { pendapatan } \\
\text { dari hasil } \\
\text { penjualan } \\
\text { bisa } \\
\text { meningkat. } \\
\text { b. Kritik dan } \\
\text { saran yang } \\
\text { selalu } \\
\text { diterima } \\
\text { dengan baik } \\
\text { karena } \\
\text { sebagai }\end{array}$ & $\begin{array}{l}\text { a. Tenaga } \\
\text { manusia } \\
\text { dan } \\
\text { manajem } \\
\text { en waktu } \\
\text { yang } \\
\text { kurang } \\
\text { diatur } \\
\text { dengan } \\
\text { baik } \\
\text { berpenga } \\
\text { ruh pada } \\
\text { kegiatan } \\
\text { promosi } \\
\text { produk } \\
\text { kurang } \\
\text { optimal. }\end{array}$ \\
\hline
\end{tabular}




\begin{tabular}{|c|c|c|}
\hline & $\begin{array}{l}\text { bahan } \\
\text { koreksi } \\
\text { untuk hal } \\
\text { positif } \\
\text { sehingga } \\
\text { perubahan } \\
\text { produk } \\
\text { dapat } \\
\text { dirasakan, } \\
\text { loyalitas } \\
\text { konsumen } \\
\text { menjadi } \\
\text { kental. }\end{array}$ & \\
\hline Threats (T) & $\begin{array}{c}\text { Strategies (S- } \\
T) \\
\end{array}$ & $\begin{array}{c}\text { Strategies } \\
(W-T)\end{array}$ \\
\hline 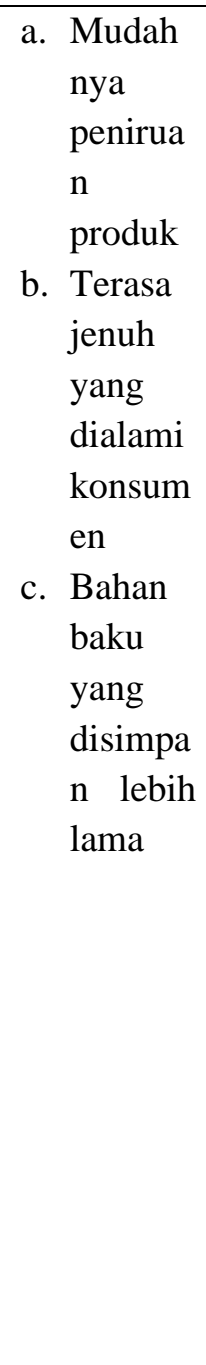 & $\begin{array}{l}\text { a. Disebabkan } \\
\text { karena } \\
\text { murahnya } \\
\text { harga } \\
\text { produk dan } \\
\text { tidak } \\
\text { mengecewa } \\
\text { kan } \\
\text { sehingga } \\
\text { ditemukan } \\
\text { banyak } \\
\text { orang yang } \\
\text { melakukan } \\
\text { peniruan } \\
\text { produk } \\
\text { perusahaan. } \\
\text { b. Perusahaan } \\
\text { dituntut } \\
\text { untuk sering } \\
\text { melakukan } \\
\text { inovasi } \\
\text { produk baru } \\
\text { agar } \\
\text { kejenuhan } \\
\text { konsumen } \\
\text { dapat } \\
\text { teratasi. }\end{array}$ & $\begin{array}{l}\text { a. Masa } \\
\text { berlaku } \\
\text { produk } \\
\text { yang } \\
\text { tidak } \\
\text { tahan } \\
\text { lama. }\end{array}$ \\
\hline
\end{tabular}

Keterangan :

Strategi $(\mathrm{S}-\mathrm{O})$ : Dengan memiliki harga yang terjangkau murah dan dapat menerima saran dari pembeli, ditambah lagi pembeli dapat melihat cara penyajian kita sehingga pembeli dapat melihat kualitas dari bahan produksi yang digunakan. Dan di dukung juga dengan inovasi produk yang ditingkatkan dan minimnya persaingan dagang.

Strategi $(S-T)$ : Dengan memiliki harga yang terjangkau dan pembeli dapat melihat cara penyajiannya, sehingga produk Sunmory Milk dapat sangat mudah ditiru dan konsumen akan mudah bosan bila tidak ada pembaruan menu di setiap bulannya, sehingga produk Sunmory Milk harus memiliki bahan rahasia, agar tidak dapat ditiru dan menjadi ciri khas tersendiri untuk produk Sunmory Milk dan di setiap periode harus memiliki inovasi baru pada menu dan promosinya.

Strategi $(\mathrm{W}-\mathrm{O})$ : Dengan kurangnya Sumber Daya Manusia (SDM) pada manajemen Sunmory Milk, kurangnya manajemen waktu karna berada pada bulan puasa dan sulitnya mencari bahan baku produk yang murah dan dituntut dengan adanya inovasi produk di setiap bulannya, sehingga manajemen Sunnmory Milk menjadi kurang maksimal dari segi promosi, ketersediaan barang yang kurang 
Revised: July, 142021

Available online : July, 152021

lengkap dan mobilitas jual beli yang kurang maksimal.

Strategi (W-T) : Dengan bahan baku yang tidak tahan lama dan kurangnya SDM, sehingga rotasi keluar masuk bahan baku di gudang menjadi lama, dan berdampak ke daya tahan bahan baku itu sendiri (expired) sehingga mengalami kerugian.

\section{Strategi Pemasaran}

Product (Produk), dengan mengedepankan kualitas dan inovasi pada minuman berbahan dasar susu, mengenalkan produk Sunmory Milk.

Price (Harga), Sunmory Milk memberikan kualitas serta menawarkan harga yang terjangkau untuk para pelanggan. Dengan mempertimbangkan keterjangkauan harga, bagusnya kualitas bahan baku yang digunakan dan persaingan harga antar pesaing yang ditawarkan sehingga membuat Sunmory Milk menawarkan harga produk yang relatif mudah dijangkau alias murah tanpa melakukan pengurangan akan mutu bahan baku yang digunakan.

Promotion (Promosi), Perusahaan melakukan promosi produk Sunmory Milk melalui media sosial online seperti aplikasi whatsapp, instagram dan facebook. Dengan dilakukannya promosi melalui media sosial maka kepuasan konsumen akan produk dapat terpenuhi dengan baik. Konsumen merasa puas sehingga promosi selanjutkan akan disebarkan melalui mulut ke mulut (word of mouth). Promosi memiliki tujuan agar konsumen mengetahui dengan pasti terkait produk yang dijual serta adanya upaya untuk menarik konsumen untuk melakukan pembelian akan produk.

Place (Tempat), Sunmory Milk mencari tempat yang strategis seperti dekat dengan area sekolah, perguruan tinggi dan dekat dengan tempat perbelanjaan. Pemilihan tempat yang tepat akan mempengaruhi dengan mudahnya produk ditemui sehingga setiap kalangan dapat lebih mudah merasakan produk tersebut.

People (Partisipan), perlu mendapat perhatian dari perusahaan bahwa adanya hubungan yang dibina dengan baik antar personal yang terlibat dalam kegiatan perusahaan, seperti relasi bisnis antara pemasok bahan baku dengan perusahaan. Hubungan yang baik akan berpengaruh terhadap kepentingan tujuan perusahaan jangka pendek maupun jangka panjang.

Process (Proses), perusahaan harus memperhatikan kelancaran proses mulai dari kedatangan konsumen atau pelanggan sampai dengan produk yang dijual dapat diterima dengan baik oleh konsumen. Pelayanan terhadap konsumen perlu 
Revised: July, 142021

Available online : July, 152021

menjadi perhatian serius oleh perusahaan agar tidak mengecewakan pelanggan.

\section{Physical Evidence (Lingkungan}

Fisik), fasilitas pendukung dari perusahaan seperti penataan stand yang baik dan menarik, pemakaian sarana dan prasarana yang harus dijaga tingkat kebersihan dan bermutu.

\section{KESIMPULAN}

\section{Simpulan}

Simpulan yang dapat diambil adalah sebagai berikut:

1. Berdasarkan matrix SWOT dapat disimpulkan bahwa perusahaan harus mempertahankan strategi kekuatan yang ada yaitu tetap menjaga keterjangkauan harga jual produk, perusahaan harus tetap menerima segala saran dan kritik konsumen untuk penyempurnaan produk yang ditawarkan agar konsistensi produk tetap dapat terjaga, perusahaan harus tetap melakukan inovasi produk secara periodik agar tingkat kejenuhan konsumen dapat teratasi dengan baik dan penentuan lokasi usaha yang strategis mudah dijangkau oleh konsumen. Selain itu, ada beberapa kelemahan perusahaan yang perlu diperbaiki terkait jumlah tenaga kerja yang memadai dan manajemen waktu yang diatur dengan baik.

2. Berdasarkan uraian terkait strategi pemasaran yang digunakan perusahaan mengacu pada bauran pemasaran 7P. Secara keseluruhan perusahaan telah melakukan indikator 7P dengan baik. Inovasi produk yang tetap terjaga, harga yang mudah dijangkau konsumen, gencarnya promosi yang telah dilakukan melalui media sosial dan aplikasi layanan masyarakat, letak lokasi usaha yang cukup strategis dimana dekat dengan area sekolah, perguruan tinggi dan pusat perbelanjaan umum. Tetapi untuk indikator yang perlu perbaikan yaitu harus adanya penambahan jumlah personal dalam penjualan dan pemasaran, proses pelayanan yang perlu ditata lagi agar konsumen lebih cepat dan tidak lama menunggu produk yang dibeli dan terkait lingkungan fisik dalam hal stand yang perlu ditata agar lebih menarik lagi, faktor penerangan stand perlu diperhatikan agar lebih jelas terlihat oleh pandangan orang banyak.

\section{Implikasi Penelitian}

1. Product (Produk). Produk awal yang digunakan oleh Sunmory Milk dengan menggunakan susu sapi murni, di balik pengolahannya yang cukup rumit yang 
dimulai dari memasaknya terlebih dahulu sehingga tidak mudah basi. Untuk mempermudah agar kerumitan dapat teratasi Sunmory Milk menggunakan susu UHT dari ultra milk, di samping lebih murah, tidak perlu membeli bahan bakar gas untuk menghangatkan dan juga lebih praktis tinggal menuang susu saja, masa kadaluarsa yang lebih lama yaitu seminggu setelah di buka.

2. Price (Harga). Dengan banyaknya pesaing dibidang yang sama sehingga Sunmory Milk harus memutar akal supaya dapat masuk dalam persaingan. Dengan mengikuti persaingan itu, Sunmory Milk melakukan pergerakan dengan menyiasati harga, melalui survei lokasi dan mencoba produk pesaing sehingga perusahaan dapat mengetahui rasa, kualitas dan akhirnya bisa menentukan harga yang sesuai.

3. Promotion (Promosi). Pada bulan ramadhan, Sunmory Milk harus memikirkan promosi yang cocok pada masa tersebut disamping bisa mendongkrak penjualan pada bulan ramadhan dan pandemi ini. Sunmory Milk melakukan pergerakan dengan mengadakan promo dengan syarat pembelian minimal dua produk
Sunmory Milk rasa apa saja akan mendapatkan free satu gelas Sunmory Tail plus takjil kurma. Dengan syarat ini Sunmory Milk dapat memberikan inovasi di bulan ramadhan dan dapat mengenalkan produk baru dari Sunmory Milk yaitu Sunmory Tail.

4. Place (Tempat). Pada perkembangan zaman saat dan masa pandemi, media sosial sangat berpengaruh untuk perkembangan usaha dan bisnis menengah ke bawah. Sehingga banyak sekali bisnis menerima pesanan (take order) melalui media aplikasi online. Untuk itu Sunmory Milk juga melakukan hal yang sama yaitu disamping membuka stand jualan juga membuka aplikasi online seperti GoFood dan menggunakan media sosial seperti instagram, facebook, whatsapp untuk menunjang penjualan.

5. People (Partisipan). Untuk mengembangkan usaha Sunmory Milk agar lebih besar dan dikenal publik, Sunmory Milk berencana untuk menjadikan usaha ini menjadi bentuk waralaba (franchise). Dengan menjadikan usaha ini menjadi franchise disamping akan meningkatkan penjualan dan dikenal oleh publik, sistem ini akan memperluas jaringan 
Revised : July, 142021

Available online : July, 152021

bisnis untuk bekerja sama dengan orang lain.

6. Process (Proses). Sunmory Milk menerapkan penjualan dengan memperlihatkan proses pembuatannya sehingga pengunjung dapat melihat proses-proses tersebut dengan menggunakan perlengkapan standar dan higienis agar pembeli menjadi lebih percaya. Sunmory Milk sebelum melakukan penjualan terlebih dahulu memperhatikan kualitas bahan baku dan peralatan pendukung .

7. Physical Evidence (Lingkungan fisik). Sunmory Milk melakukan survei terlebih dahulu untuk memulai usaha dengan menentukan kualitas produksi, kemasan, lokasi dan lalu lintas (traffics) kendaraan.

\section{Saran}

1. Karena keterbatasan informan yang dijadikan sample penelitian, peneliti ingin agar penelitian selanjutnya lebih banyak lagi melibatkan jumlah informan dengan penyebaran usia dan jenis kelamin yang lebih merata agar keabsahan penelitian lebih ditingkatkan lagi.

2. Pembuatan SWOT analisis dalam menentukan strategi pemasaran tidak saja berdasarkan indikator bauran pemasaran seperti pada penelitian ini tetapi bisa menggunakan variable penelitan yang lebih luas lagi cakupannya. Terkait hal ini dapat menjadi pertimbangan peneliti selanjutnya.

\section{DAFTAR PUSTAKA}

Assauri, 2017. Manajemen Pemasaran: Konsep, Dasar, dan Strategi, Jakarta: PT. Raja Grafindo Persada.

Cahyono, Puguh. 2016. Implementasi Strategi Pemasaran dengan Menggunakan Metode SWOT dalam Upaya Meningkatkan Penjualan Produk Asuransi Kecelakaan dan Kematian pada PT. Prudential Cabang Lamongan. Jurnal Penelitian Ilmu Manajemen. Volume 1(2); 2502-3780.

Chandra, 2017. Strategi Pemasaran. Islamic. Jakarta: Universitas Bina Sarana Informatika.

Freddy, Rangkuti, 2016. Analisis SWOT: Teknik Membedah Kasus Bisnis. Jakarta: PT. Gramedia Pustaka Utama. 19

Nuary, Nizar Sapta. 2016. Strategi Pemasaran dengan Pendekatan Analisis SWOT pada PT. Super Sukses Motor Banjarmasin. Jurnal Ilmiah Ekonomi Bisnis. Volume 2(1); 30-42.

Rangkuti, 2017. Teknik Membedah Kasus Bisnis Analisis SWOT, Jurnal. Yogyakarta: Universitas Sanata Dharma Yogyakarta . 26

Rangkuti, 2017. Matrik SWOT alat yang dipakai untuk menyusun faktorfaktor strategis perusahaan, Jurnal. Yogyakarta: Universitas Sanata Dharma Yogyakarta. 83-84 
Received: July, 112021

Revised : July, 142021

Available online : July, 152021

Sugiyono, 2016. Metode Penelitian

Kuantitatif, Kualitatif dan R\&D.

Bandung: PT Alfabet. 